\title{
北海道東方沖地震時にオホーツク海沿岸で観測された津波
}

\author{
気象庁気像研究所* 中 村 浩 二 \\ 東京大学地震研究所** 荒 井 賢 一
}

\section{A Small Tsunami Observed along the Coast of the Okhotsk Sea Accompanied with the 1994 Hokkaido Toho-Oki Earthquake}

\author{
Kouji NAKAmURA \\ Seismology and Volcanology Research Division, Meteorological Research Institute, Japan \\ Meteorological Agency, 1-1, Nagamine, Tsukuba, Ibaraki 305, Japan \\ Ken'ichi Arai \\ Tsunami and Storm Surges Laboratory, Earthquake Research Institute, University of Tokyo, \\ 1-1-1, Yayoi Bunkyo-ku, Tokyo 113, Japan
}

(Received October 26, 1995; Accepted December 22, 1995)

\begin{abstract}
A tsunami was generated by the 1994 Hokkaido Toho-Oki earthquake and was observed at tidal stations on the Pacific coast of the Japanese Islands. It was observed also at several tidal stations on Hokkaido coast of the Okhotsk Sea, where the arrival of the initial wave was recorded earlier than the expected time: for example, the initial motion of the tsunami was recorded at Utoro 17 minutes after the mainshock, while that the theoretically expected tsunami arrival time from the source in the south sea region of Shikotan Island is 80 minutes after it. We tried to estimate the location of the source of the early coming waves by drawing the inverse refraction diagram from each station. We suggest two probable locations of the source; one is the area 80 kilometers north of Abashiri, and the other is the area 40 kilometers north of the tip of Shiretoko Peninsula. The seismic activity at both of those areas is poor. So, we cannot judge that the early coming waves were generated by some another events. Both of those areas are situated in the continental slope regions and with steep slopes. We suppose that a land slide at either of those areas caused the early coming waves.
\end{abstract}

Key words: Hokkaido Toho-Oki Earthquake tsunami, Early coming waves, Okhotsk Sea, Refraction diagram, Numerical simulation.

§1.はじめに

1994 年 10 月 4 日 22 時 23 分頃, 北海道東方沖の北 緯 43 度 22 分, 東経 147 度 40 分, 深さ $30 \mathrm{~km}$ を震源 とする M 8.1 の地震が発生した [小泉 (1994)]. この地 震により, 北海道東方沖を波源とする津波が発生し, 根 室半島の花咲港で最大振幅 $173 \mathrm{~cm}$ の津波が観測された 他, 北海道から西日本にわたる太平洋側の広い範囲で津 波が観測された。

この津波は, 同様に北海道のオホーック海沿岸であ観 測された。しかし、これらのオホーック海沿岸の港で観

* $\mathbf{7} 305$ 茨城県筑波市長峰 1-1

** $\overline{\mathbf{T}} 113$ 東京都文京区弥生 1-1-1
測された津波の第一波の到達時刻は, 北海道東方沖の波 源から予測される時刻よりもかなり早かった。 その一番 典型的な例が宇登呂港（オホーック海側）と花咲港（太 平洋側）で, 宇登呂港では, 地理的に明らかに震源域に 近い花咲港よりあかなり早い時刻に津波か観測されてい る.

これは, オホーック海沿岸では北海道東方沖の波源と は異なる波源からの津波を観測したことを示していると 考えられる.

以下では，従来の津波逆伝播図を用いた波源域の推定 手法を用いてその波源の推定を試み, その結果を数值計 算によるシミュレーションで検証した. 


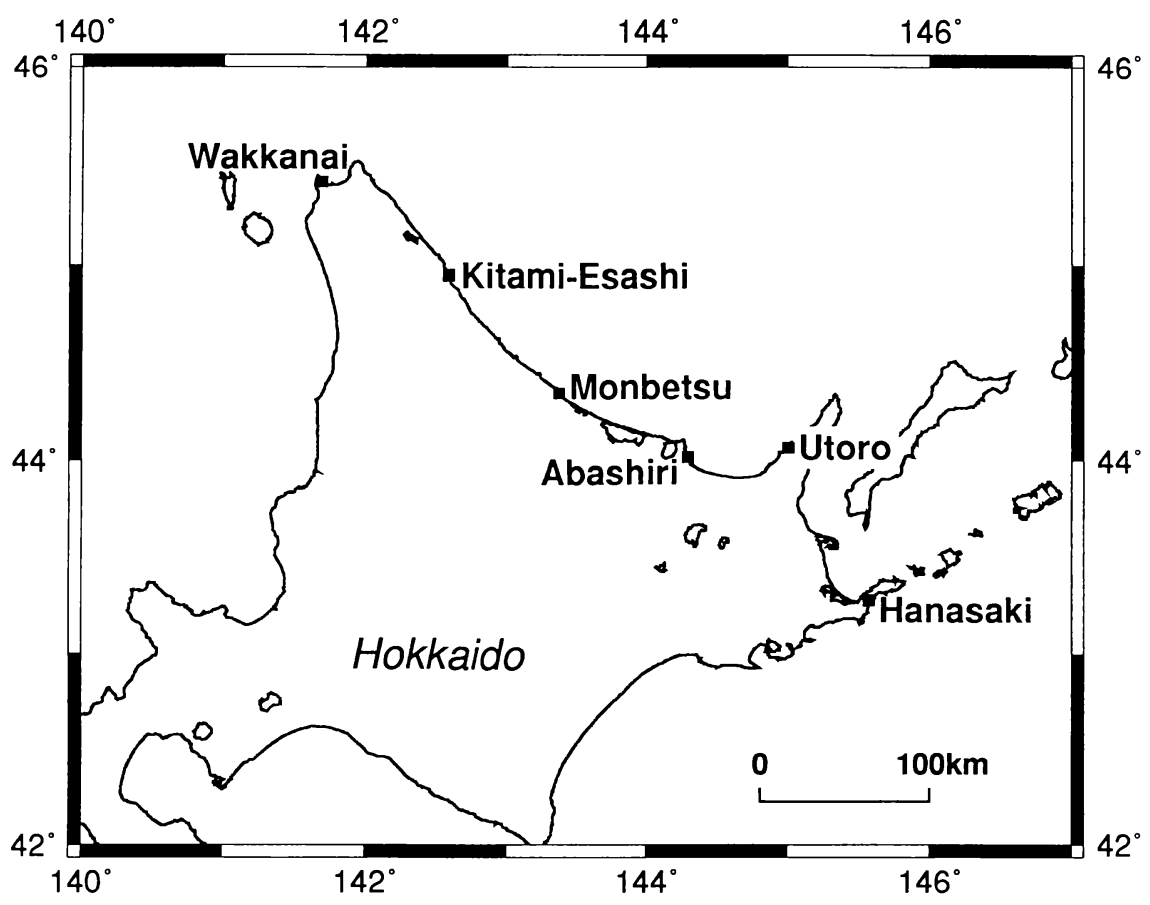

Fig. 1. Distribution of tidal stations along the Okhotsk Sea.

\section{§ 2. 津波の到達時刻}

\section{1 各地の到着時刻}

津波の資料として用いた，各検潮所の位置を Fig. 1 に 示す.オホーツク海沿岸の稚内 (気象庁), 北見枝幸, 紋 別 (北海道開発局), 網走 (気象坾), 宇登呂 (北海道開 発局）の 5 ケ所の検潮記録 (Fig. 2(a)〜 (e)) の複写記録を 使用した。

これらの記録から第一波の到着時刻を決定したのが図 中の矢印 (白), その時刻を Table 1 に示す. 最終的な到 着時刻は, 記録紙上の読み取り值に, 時刻ずれの補正值 を加えたものである。

Fig. 2 から分かるとおり, 宇登呂で記録されている津 波が非常に顕著で，それに次いで北見枝幸の記録が明瞭 である。

\section{2 早すぎる到着時刻}

Fig. 3 に, 本震の震源域から約 $50 \mathrm{~km}$ 離れた場所に 位置する花咲（気象庁）の検潮記録を示す．本震の震源 域から $250 \mathrm{~km}$ 程離れた場所に位置する, 宇登呂の検潮 記録 (Fig. 2(e)) と比較した。宇登呂の第一波到達時刻の 方が花咲のそれよりも早いことがよく分かる.

この宇登呂を含めたオホーック海沿岸の各検潮所の第 一波到達時刻を検討するために, Fig. 4 に北海道東方沖 地震津波の波源からの伝播図を示す。网から分かるとお り，この波源からの津波は地震発生後，宇登呂，網走，
紋別，北見枝幸，稚内にそれぞれ，およそ 70 分，80 分， 110 分, 120 分, 180 分後に到着することが予测される. しかし，実際には Table 1 に示すとおり，17 分, 28 分, 45 分, 66 分, 135 分後となっている.つまり, オホーツ ク海側の各地で, 北海道東方沖からの津波の到達よりも 50〜60 分も早く津波が観測されていることになる.

Fig. 3 には矢印（黒）で，北海道東方沖からの津波が到 達したと考えられる時刻を示してある．各地でこの時刻 付近を境に津波の波形パターンの変化が見られる.特に 宇登呂では，この時刻を境に津波の周期変化が明瞭であ り，そのことはこの時刻の前と後の津波波形をスペクト ル解析した結果からもはっきり分かる (Fig. 5). また同 様に稚内, 紋別, 網走でも振幅と周期の変化が認められ る.

これらのことから，オホーック海浻岸では北海道東方 沖の波源からの津波の前に，別の波源からの性質の異な る波を観測したと考えられる。

\section{§ 3. 逆伝播図による波源の推定}

\section{1 推定方法}

地震などによる津波は，一般に海の水深に比べて波長 が十分長いので，その伝播速度は線形長波の位相速度, すなわち $V=\sqrt{g h}(g$ : 重力加速度, $h$ : 水深) で与えら れる. 

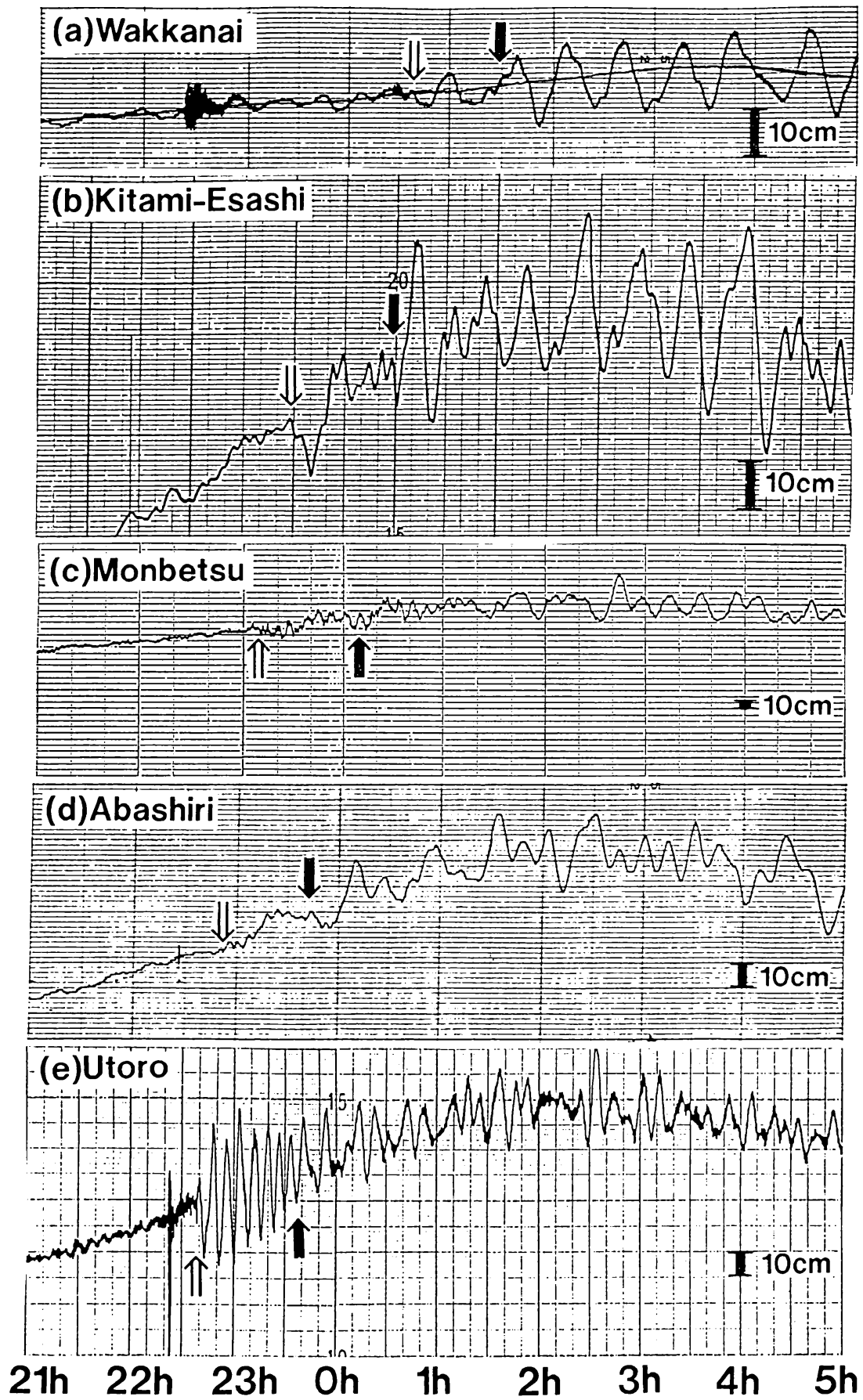

Fig. 2. Tide gauge records at (a) Wakkanai, (b) Kitami-Esashi, (c) Monbetsu, (d) Abashiri, and (e) Utoro on Oct. 4, 1994. A white arrow indicates the arrival time of the initial wave. A black arrow indicates the expected tsunami arrival time from the source region in the south sea of Shikotan Island. 
このことと波に関するホイヘンスの原理を使えば，あ る波源から津波が伝播していく様子を表した津波伝播図 を作成することが出来る [気象庁 (1988)]. 例えば, Fig. 4 の津波伝播図はこのような原理に基づいて，推定され た波源域からの津波の伝播を計算して作成された。

逆に娭潮所を波源とした伝播図, すなわち津波逆伝播 図を作成しておくと, 各地の津波第一波到着時刻から津 波の波源域を推定することが出来る.

検潮記録から第一波の到着時刻が読み取ってあれば, 地震発生から津波到着までの経過時間（伝播時間） $T$ が 分かる. そして, 逆伝播図を用いて, ある検潮所から経 過時間 $T$ で伝播する仮想的な逆伝播波面を求められる. この逆伝播波面を各検潮所について作成すれば, 通常は

Table 1. The arrival time of the initial wave at the tidal stations.

\begin{tabular}{|l|c|c|}
\hline Tidal Station & arrival time & travel time \\
\hline Wakkanai & $0 \mathrm{~h} 38 \mathrm{~m}$ & $135 \mathrm{~min}$. \\
\hline Kitami-Esashi & $23 \mathrm{~h} 29 \mathrm{~m}$ & $66 \mathrm{~min}$. \\
\hline Monbetsu & $23 \mathrm{~h} 8 \mathrm{~m}$ & $45 \mathrm{~min}$. \\
\hline Abashiri & $22 \mathrm{~h} 51 \mathrm{~m}$ & $28 \mathrm{~min}$. \\
\hline Utoro & $22 \mathrm{~h} 40 \mathrm{~m}$ & $17 \mathrm{~min}$. \\
\hline
\end{tabular}

それらの波面に内接する形で津波の波源が決定出来る.

\section{2 各検潮所の逆伝播波面}

Fig. 6 に紋別港検潮所の逆伝播図を例として示す.こ のような逆伝播図を稚内, 北見枝幸, 紋別, 網走, 宇登 呂の各検潮所について作成した。 そして, Table 1 の伝 播時間に基づいて各検潮所からの逆伝播波面を示したの が Fig. 7 である.これらの波面は, 北海道東方沖地震発 生時刻の仮想的波面ということになる。

\section{3 逆伝播図から推定される波源}

Fig. 7 の各検潮所の逆伝播波面の分布を見ると, オ ホーツク海内の 2 ケ所に波面が集まっていることが分

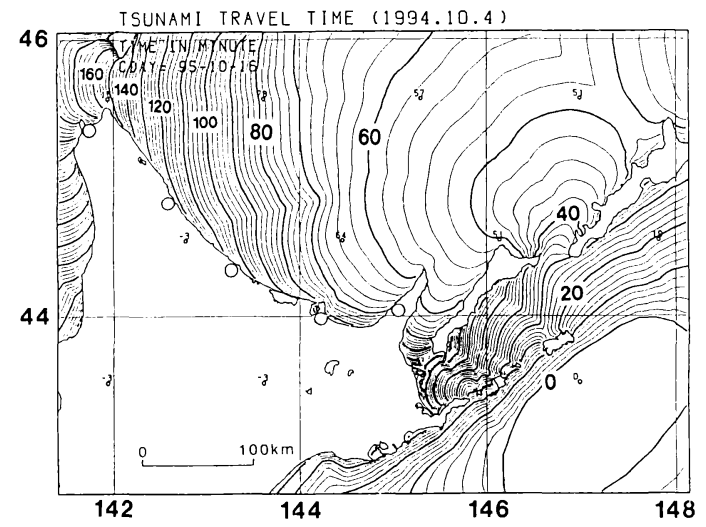

Fig. 4. Refraction diagram of the 1994 Hokkaido Toho-Oki Tsunami (time interval: 12 $\min )$.

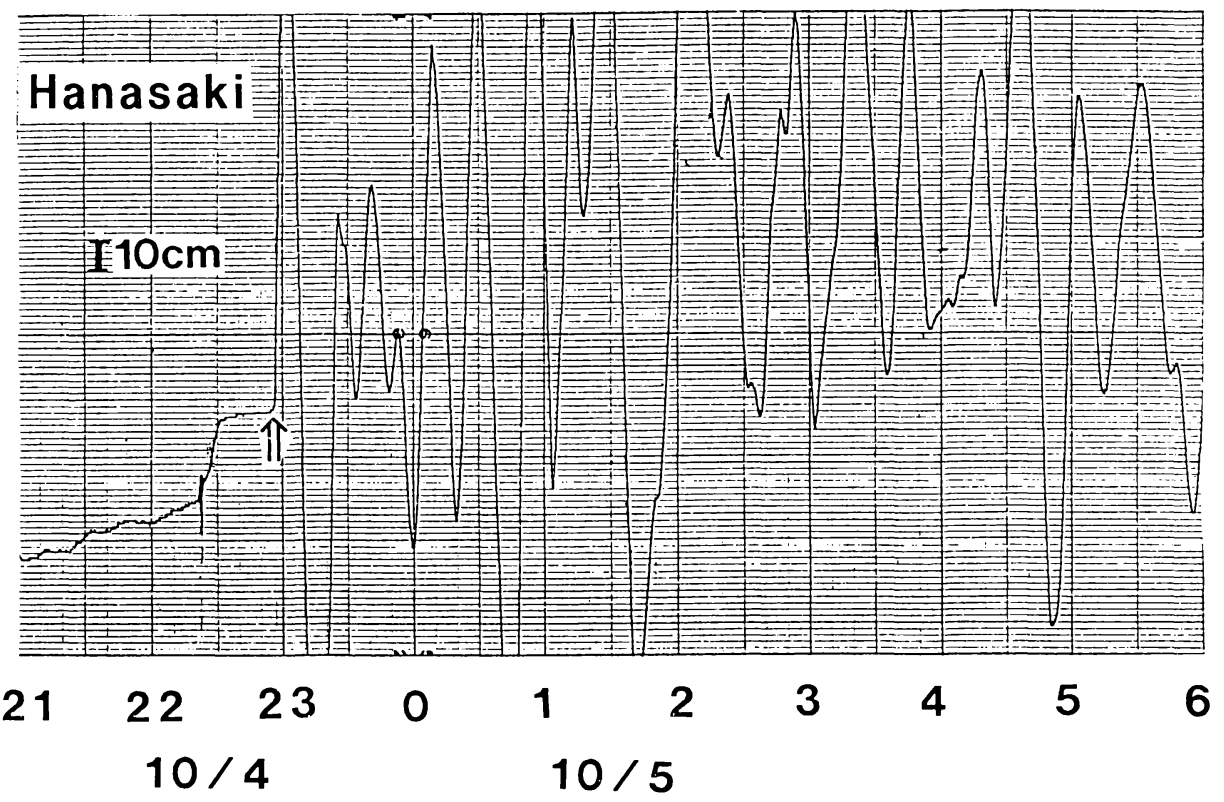

Fig. 3. Tide gauge records at Hanasaki on Oct. 4, 1994. 


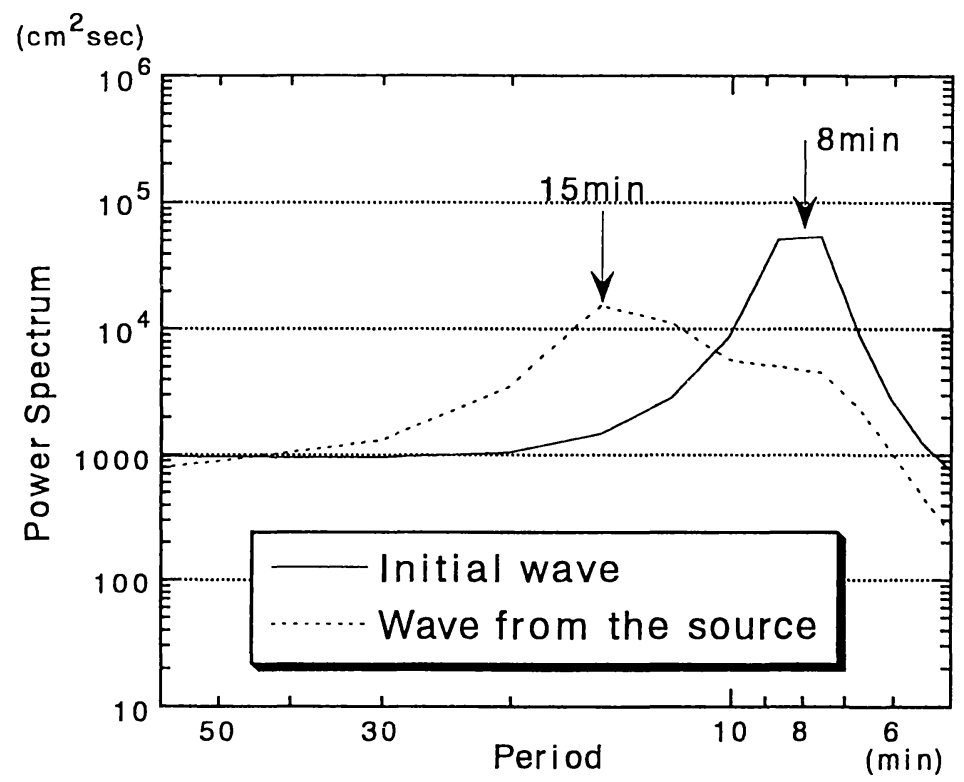

Sampling interval $\mathrm{dt}=30$ (sec)

The number of data $N=121$

Fig. 5. Power Spectra of tide gauge record at Utoro. It was calculated by MEM method. The sampling interval is 30 seconds and one set of the analysed data contains 121 samples. The duration of the run is the following.

real line: Initial wave ( $22 \mathrm{~h} 40 \mathrm{~min}$ to $23 \mathrm{~h} 40 \mathrm{~min}$, October 4 ), dotted line: Wave from the source (23 h $40 \mathrm{~min}$, October 4 to $0 \mathrm{~h} 40 \mathrm{~min}$, October 5).

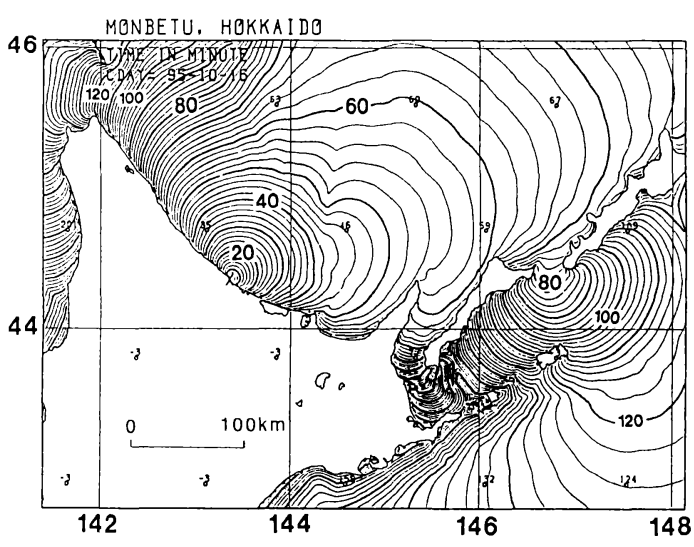

Fig. 6. Inverse refraction diagram from Monbetsu (time interval: $2 \mathrm{~min}$ ).

かる. 1 つは網走北方の北緯 44.7 度, 東経 144.3 度を中 心とした狭い領域に稚内, 北見枝幸, 紋別, 網走, 宇登 呂の 5 つの検潮所の波面が集まっている．あう1つは, 知床半島北方の北緯 44.7 度, 東経 145.5 度を中心とし た狭い領域に稚内, 網走, 宇登呂の 3 つの検潮所の波面 が集まっている.

波面の集まり方から判断すると，5つの検潮所の波面
が集まっている網走北方が波源の第一候補として考えら れる. しかし，紋別の第一波が微弱で読み取りに任意性 が残ること, および北海道東方沖地震 (本震) に伴う津 波の波源域からの波が到達する前の部分では，宇登呂の 振幅が他の 4 つの検潮所に比べてかなり大きいことか ら, 知床半島北方に波源があった可能性についても同様 に検討する必要がある。

以上は, 北海道東方沖地震発生時刻である 22 時 23 分を基準にして考えた逆伝播波面による推定である.し かし，仮に北海道東方沖地震に起因する現象がオホーツ ク海で起こり，それが津波発生につながったと考えるな ら, 因果律からいってその現象は 22 時 23 分以降に起 こったことになる．従って，厳密にはその現象による波 源の推定を行う場合にも 22 時 23 分以降の時刻を基準 に考える必要があるが, 伝播時間を 1〜2 分程度ずらし ても，逆伝播の波面が網走北方及び知床半島北方の狭い 領域に集まっている状態に変化はない.

これらのことから, 北海道東方沖地震時にオホーック 海浻岸で最初に観測された津波は，網走北方（北緯 44.7 度, 東経 144.3 度を中心とした領域）もしくは, 知床半 島北方（北緯 44.7 度，東経 145.5 度を中心とした領域） を波源とした津波であると考えられる. 


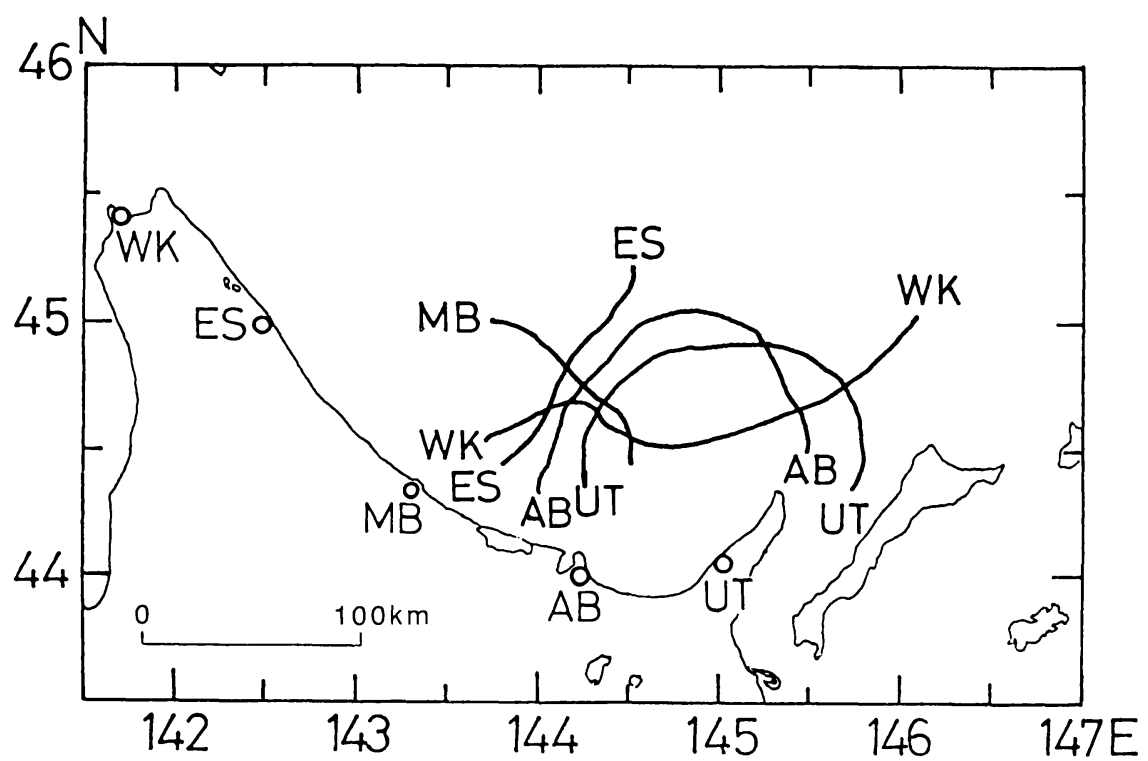

Fig. 7. The wave fronts of the inverse refraction diagram on $22: 23$, Oct. 4, 1994 . UT: Utoro, AB: Abashiri, MB: Monbetsu, ES: Kitami-Esashi, WK: Wakkanai

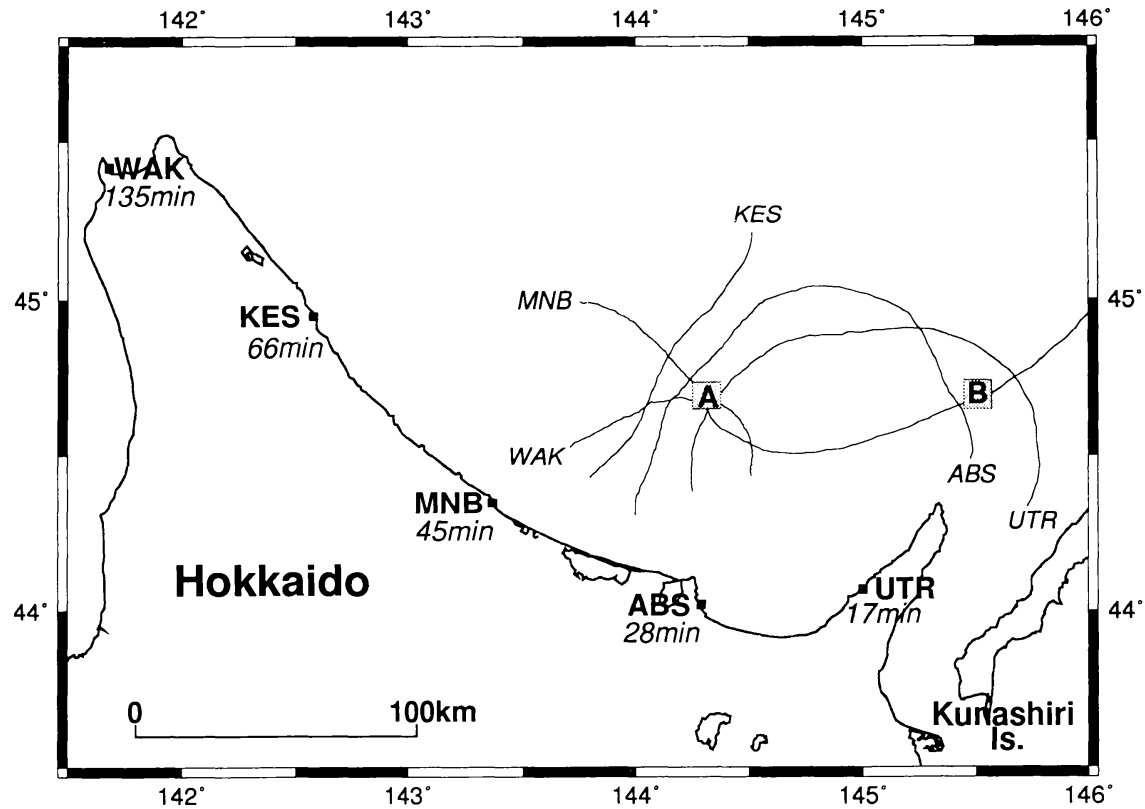

Fig. 8. Supposed locations of the source of the early coming waves; one is the area A, 80 kilometers north of Abashiri, and the other is the area B, 40 kilometers north of the tip of Shiretoko Peninsula.

\section{§4. 数值シミュレーションによる波源域の検証}

\section{1 数值シミュレーションの方法}

前章で述べたように，津波逆伝播図による考察から津 波第一波の波源域は網走北方（以下，領域 A と呼ぶ）, 又は知床半島北方（以下，領域 B と呼ぶ）である可能性 を指摘できる．次に，波源域ではないかと考えられた 2
つの領域に地款变動を与えることにより, 津波伝播の数 值シミュレーションを行った。 これには, 浅海波の方程 式 (極座標系) を差分法で解く従来の手法を用い, 海底 摩擦等の非線形な効果は省略した。つまり, 運動方程式 として, 

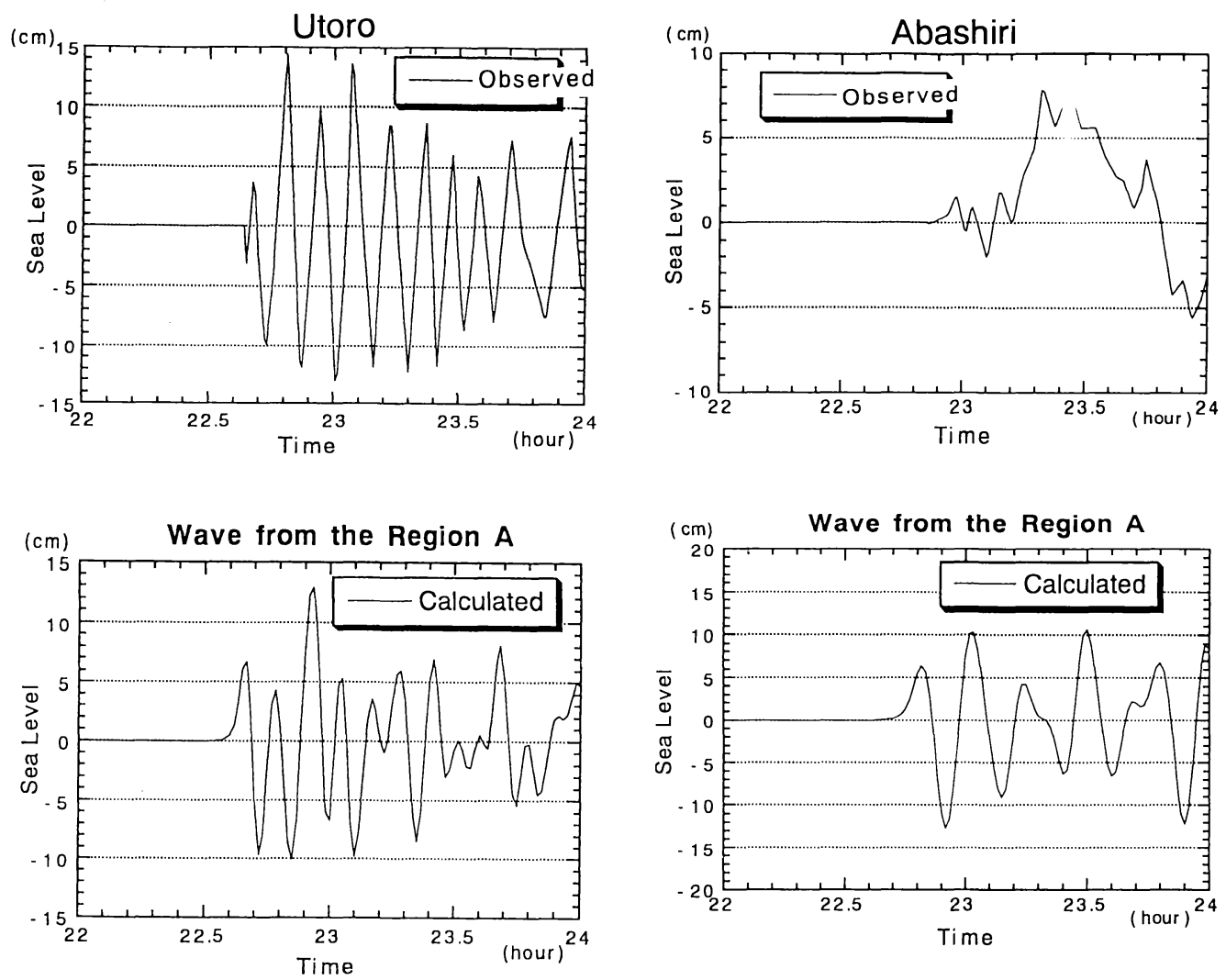

Wave from the Region $B$

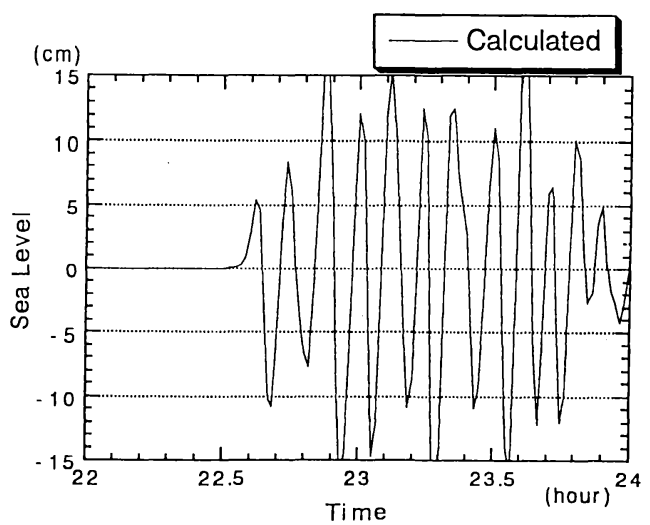

(a)

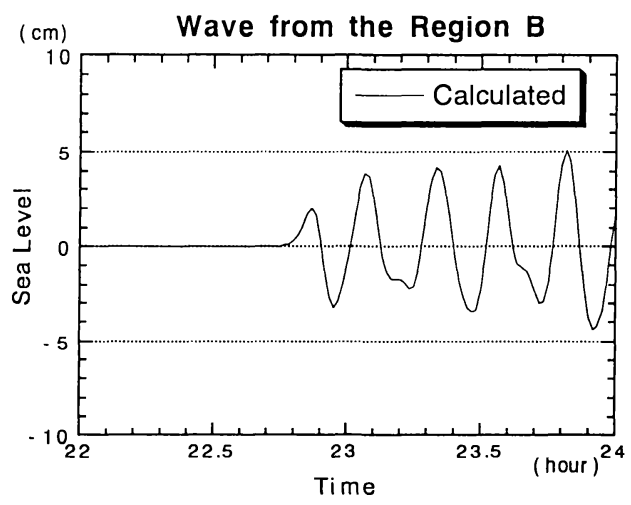

(b)

Fig. 9. Comparison of observed and calculated (from A and B regions) tsunami waveforms. 

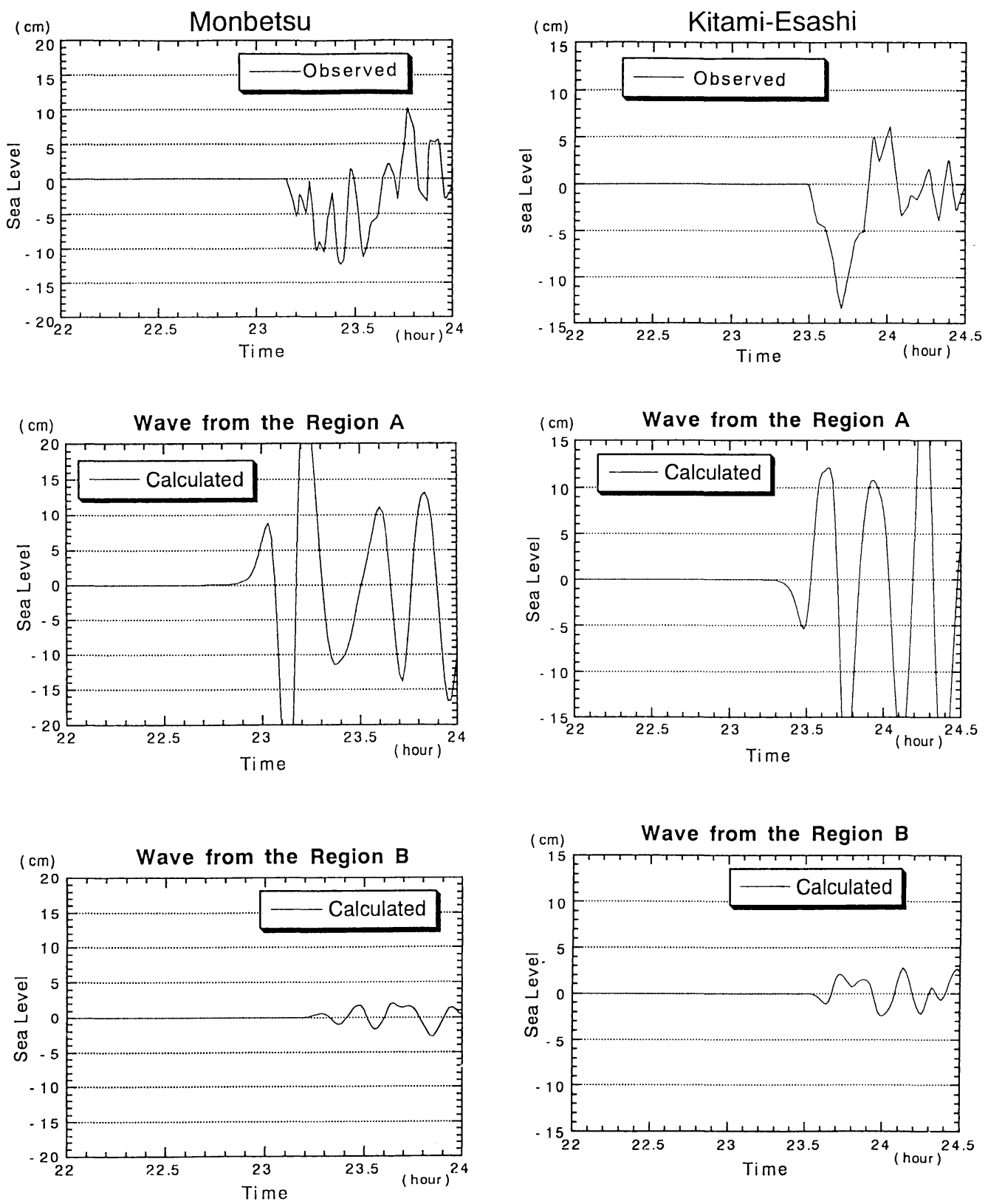

(c)

(d)

Fig. 9. Comparison of observed and calculated (from A and B regions) tsunami waveforms. 

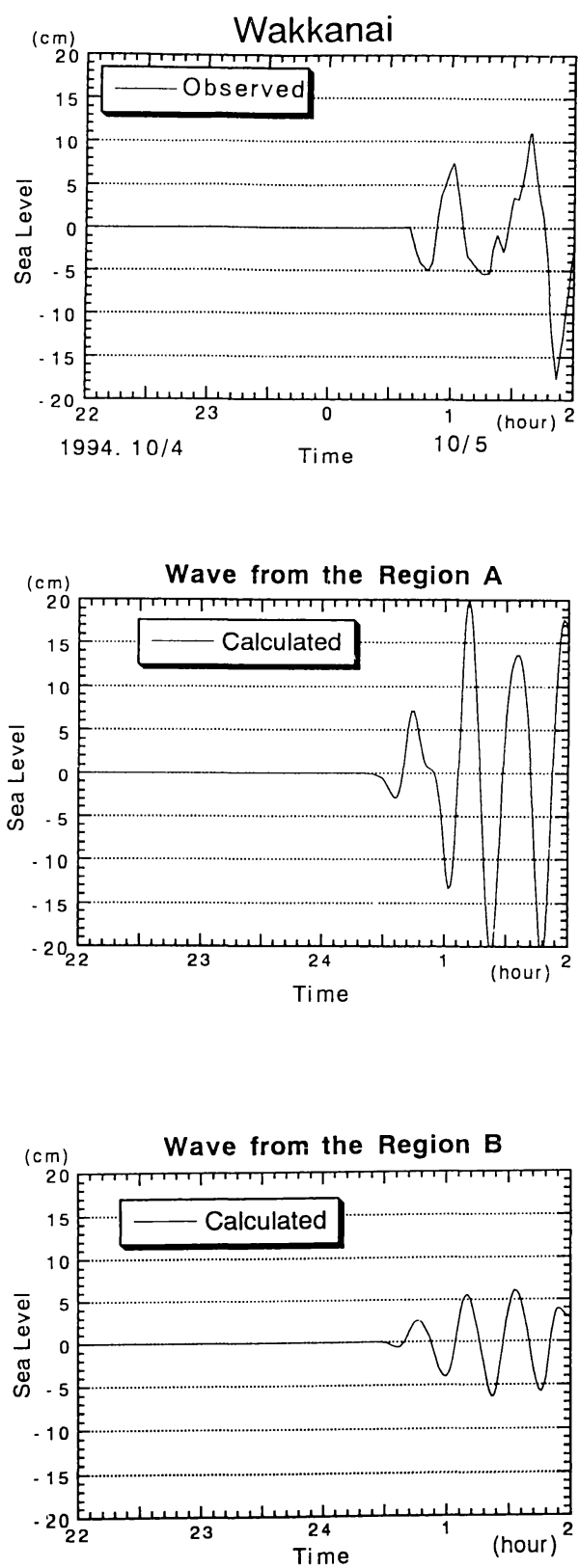

(e)

Fig. 9. Comparison of observed and calculated (from $\mathrm{A}$ and $\mathrm{B}$ regions) tsunami waveforms.

$$
\begin{gathered}
\frac{\partial Q_{\lambda}}{\partial t}=-\frac{g h}{R \cos \theta} \frac{\partial \zeta}{\partial \lambda} \\
\frac{\partial Q_{\theta}}{\partial t}=-\frac{g h}{R} \frac{\partial \zeta}{\partial \theta}
\end{gathered}
$$

また, 連続の式としては,

$$
\frac{\partial \zeta}{\partial t}=-\frac{1}{R \cos \theta}\left\{\frac{\partial Q_{\lambda}}{\partial \lambda}+\frac{\partial}{\partial \theta}\left(Q_{\theta} \cos \theta\right)\right\}
$$

を用いた. 尚, $\lambda$ は東方向を正に, $\theta$ は北方向を正におい た.ここで， $Q_{\lambda}, Q_{\theta}$ はそれぞれ経度方向, 緯度方向の流

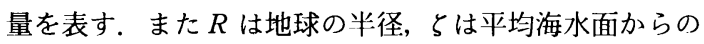
水位上昇量, $t$ は時間である. このシミュレーションに おいて, 水深デー夕は全計算領域で, 1 分格子間隔に補 間した。

数值シミュレーションでは, 領域 A に地殼変動を与 える (Fig. 8) ことにより津波伝播計算を行い, オホーツ ク海側の 5 つの検潮所に抢ける津波波形を計算により 求めた。 そして計算波形を, 検潮所で得られている観測 波形と比較した. シミュレーションに用いるパラメー ターとしてまず最初に, Fig. 7 を参考にして変動域の大 きさを仮定した，領域 A での変動は, 長さ $10 \mathrm{~km}$, 幅 $10 \mathrm{~km}$ の傾斜の無い面を鉛直方向に変位させた. 領域 B にも地壳変動を与え (Fig. 8), 上記と同様の比較を試み た. Fig. 7 を参考にした結果, 領域 Bでの变動も長さ 10 $\mathrm{km}$, 幅 $10 \mathrm{~km}$ の傾斜の無い面を鉛直方向に変位させ, 計算を行った.

次は, 鉛直方向の変位量の仮定である.ここでは, 提 唱された A と B のどちらの波源からあ近距離に位置す る宇登呂, 網走の観測波形の振幅をより良く再現できる よう, 試行錯䛊的に鉊直変位量を変えながらモデルを改 善していった。 また紋別, 北見枝幸, 稚内での計算波形 もモデルを改善する際の手掛かりとした，最終的に，領 域 A に与える変位量を $5 \mathrm{~m}$, 一方領域 B に与える変位 量も $5 \mathrm{~m}$ とした. 以下では, 計算波形を観測波形と比較 しながら考察を進める。

\section{2 シミュレーションの結果からの考察}

Fig. 9(a)〜(e) には, 宇登呂〜稚内における観測波形と 領域 $\mathrm{A}, \mathrm{B}$ から計算した波形との比較を示す. 尚, 各観測 記録は天文潮汐の補正を行ったものである.ここで，各 検潮所について津波第一波の到達時刻の再現性, 及び振 幅の再現性の良悪を 3 段階で Table 2(a), (b) に示す.

波源域を A と仮定した場合でも B と仮定とした場合 であ, 宇登呂と網走に関しては第一波の到達時刻, そし て振幅の大きさ共に再現性は良いと言える.これは, 波 源域から近い検潮所であり，伝播距離が短いためであ る. オホーツ海側にある 5 つの検潮所の中で早い到達を した津波の部分の振幅を比べると, 宇登呂で特に大き い. また宇登呂では, 本震の波源域から到達した津波で はなく, 早く到達した津波が最大波を発現している.こ のことからも波源域は領域 A か B のいずれかと推定し て間違いなさそうである. 一方, 網走の観测波形を見る と, 第一波到達後 30 分間ほどは振幅がたいへん小さい. この原因は, まだ不明であり, この 30 分間の部分は数 值シミュレーションであ領域 A, B のどちらを仮定して 
Table 2. Correlation between observed and calculated early coming waves at each station.

(a) The case that we suppose the region $\mathrm{A}$.

\begin{tabular}{|c|c|c|c|c|c|}
\hline & 宇登呂 & 網走 & 紋別 & 北見枝幸 & 稚内 \\
\hline 到達時刻 & 良 & 良 & 悪 & 悪 & やや良 \\
振幅 & 良 & やや良 & やや良 & やや良 & 良 \\
\hline
\end{tabular}

(b) The case that we suppose the region $\mathrm{B}$.

\begin{tabular}{|c|c|c|c|c|c|}
\hline & 宇登呂 & 網走 & 紋別 & 北見枝幸 & 稚内 \\
\hline 到達時刻 & 良 & 良 & やや良 & 良 & やや良 \\
振幅 & 良 & やや良 & 悪 & 悪 & やや良 \\
\hline
\end{tabular}

あ再現しにくい.

逆伝播図で紋別と北見枝幸の波面から波源域と期待さ れる領域 A を仮定した場合，紋別と北見枝幸では共に， 第一波の到達時刻を再現できない. シミュレーションに より計算された津波の到達時刻の方が，観測されたそれ よりあかなり早いという矛盾である.これは，検潮所近 傍での水深データの精度の違いによる可能性がある．逆 伝播図作成にあたって用いた水深データの格子間隔は $30 \mathrm{~m}$ であるのに対して, シミュレーションでは検潮所 付近でも格子間隔 1 分（約 $1300 \mathrm{~m}$ ）のあのを用いた. 紋別や北見枝幸への津波伝播経路は，水深の浅い地域に 相当するため，格子間隔は津波伝播時間におおきく影響 するのかむしれない. 1 分格子間隔にした結果では, 領 域 Bを仮定した場合の方が到達時刻は良く再現される. また振幅については，どちらを波源域としても観測波形 とあまり良い相関は得られないが, 領域 A の方が再現 度が高く見える.

稚内に関しては, 領域 $\mathrm{A}, \mathrm{B}$ のどちらで津波を発生さ せても到達時刻, 振幅ともに比較的良く一致する。 いず れの領域も，逆伝播図から期待される波源域に相当す る.

次に，津波初動の押し引きについて述べる．観測波形 の初動は, 網走で明瞭な押しで始まっている.この網走 の初動は, シミュレーションで得られた網走の計算波形 も押しを再現している. 他の 4 地点の観測波形の初動 は，すべて引きで始まっている，4地点のうち，北見枝 幸と稚内に関しては, 計算波形屯初動をほぼ再現してい ると言える. しかし, 宇登呂と紋別の計算波形は初動が 押しになっていて, これは観測波形の初動と矛盾してい る.これについては, 観測波形の解釈のしかた, 及び津 波発生のメカニズムについて今後検討が必要な課題と なった。

以上の考察で, 紋別と北見枝幸の到達時刻の問題は未

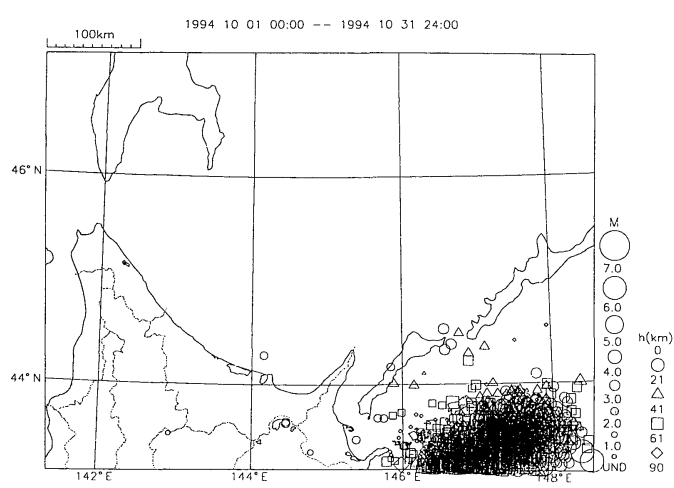

Fig. 10. Epicenter distribution of earthquakes observed by JMA (Oct. 1, 1994-Oct. 31, 1994, depth $\leq 90 \mathrm{~km})$ in the Okhotsk Sea area.

解決である. それでも宇登呂, 網走, 稚内についての考 察から，早く到達した津波の波源域は領域 A, B のどち らかであると推定される.

\section{§ 5. 発生要因の考察}

津波は, 多くの場合は地震の断層運動にともなう海底 変形によってひきおこされるが, 火山噴火 [UNOKI et al. (1953)] や山体崩壊 [相田 (1977)], 水河の崩壊など他の 要因によって引き起こされる例あある.

今回の津波は，その波源域がオホーック海内に推定さ れることから, 北海道東方沖地震そのものとは別に要因 を考えなければならない. まず, 北海道東方沖地震と時 を同じくして推定波源域（A または B) 周辺で地震が発 生して津波を発生させたことが考えられる。しかし，

Fig. 10 に示す北海道東方沖地震発生前後のオホーツク 海内の地震の活動状況からその可能性は否定される.

そこで, 我々は津波の発生要因として, 北海道東方沖 地震発生と同時刻に発生した海底地滑りの可能性を提唱 する. Fig. 11 は, オホーツク海の海底地形（水深分布） 


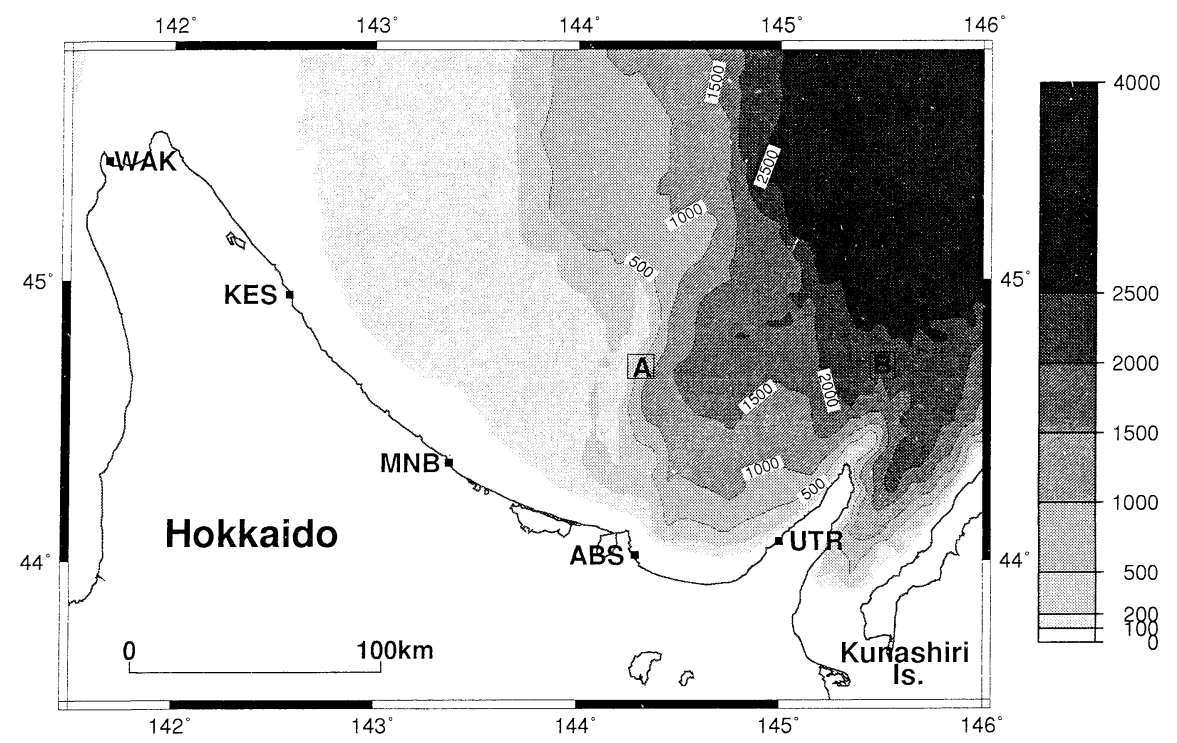

Fig. 11. Map of topography of sea bottom arround Okhotsk Sea region (Japan Marine Safety Agency).

図である. 領域 $\mathrm{A}$ および $\mathrm{B}$ はいずれも水深が急に変わ る地形となっていて, 海底地滑りの発生しやすい地形に なっていると言える. 特に, 領域 A は活断層を伴う断層 崖と重なっていて [活断層研究会 (1991)] 構造的にも弱 いことが推定できる.

これらの地形で, 北海道東方沖地震の強い地震動に よってある程度大きな地滑りが発生すれば, それに伴っ て今回報告したような津波が発生することは十分に考え られる. 実際, 北海道の全域で強い摇れが観測されたこ とからあ, オホーック海の海底むかなりの摇れにさらさ れたと推定できる. 特に領域 B は震源域に近いことか ら, 領域 $\mathrm{A}$ と比べてかなり強い摇れにさらされたと考 えられる.

\section{§6. 今後の課題}

以上の解析と考察を通して, 北海道東方沖地震に際し てオホーツク海沿岸で最初に観測された津波の波源がオ ホーツク海内にあり, その候補地が網走北方もしくは知 床半島北方に絞られることを示した．また，その津波の 発生要因が非地震性のもので, 海底地滑りの可能性があ ることを指摘した。

しかしながら, 指摘した 2 ケ所の波源域のうちのどち らが真の波源であるか決めるには至らず, また海底地滑 りの可能性についてあ, それを確かめる直接的な証拠は 今のところ得られていない. 一方, 国土地理院の GPS 観
測により, 知床半島で東方向に $50 \mathrm{~cm}$ を越える水平変 動が認められた。この変動で, 津波が発生した可能性む 指摘されている [谷岡・佐竹 (1995)].

\section{謝辞}

本研究では, 気象庁, 海上保安庁, 北海道開発局の所 管の検潮所で観測された記録を使わせて頂きました，考 察を進める上では, 気象研究所地震火山研究部 岡田正 実室長, 東京大学地震研究所 都司嘉宣助教授から有益 な助言を頂きました．また，査読者による適切な指摘は， 本稿を改善する上に非常に役立ちました，合わせてここ に，感謝の意を表します。

\section{文献}

相田 勇, 1977, 山崩れによる津波, 海洋科学, Vol. 88, 103-110.

活断層研究会, 1991, 新編日本の活断層, 付図 I.

気象庁, 1988, 地震観測指針 (調査編), 63-96.

小泉岳司, 1994, 平成 6 年 (1994 年) 北海道東方沖地 震 (速報), 気象, 12, 4-7.

谷岡勇一郎・佐竹健治, 1995, 1994 年北海道東方沖地 震はスラブを裂いた, 地球惑星科学連合学会合同大会 講演予稿集, No. 1, 152.

Unoki, S. and M. Nakano, 1953, On the CauchyPoisson Wave Caused by the Eruption of a Submarine Volcano., Oceanogr. Mag., 4, 119-141. 